\title{
Kadar 8-Oxo-7, 8-Dihydro-2'-Deoxyguanosine (8-Oxo-Dgsn) Dalam Urine Sebagai Biomarker Penuaan Pada Pasien Tb Paru
}

\author{
Cathrine Meryani Wijaya*1, Arif Santoso' ${ }^{1}$, Firdaus Hamid ${ }^{1}$, Suryani As'ad', \\ Agussalim Bukhari ${ }^{1}$, Alfian Zainuddin ${ }^{1}$ \\ ${ }^{1}$ Program Studi Ilmu Biomedik, Fakultas Kedokteran, Universitas Hasanuddin \\ Author's Email Correspondence (*): catherinemeryani@gmail.com \\ $(+081245507117)$
}

\begin{abstract}
ABSTRAK
Proses penuaan merupakan proses fisiologis yang tidak dapat dihindari. Pengukuran 8-oxo-dGsn dalam urin berpotensi sebagai cara baru untuk mengevaluasi proses penuaan dalam menentukan dan memperkirakan usia fisiologis. Penelitian ini betujuan untuk mengetahui kadar 8-Hydroxydeoxyguanosine (8-OHdG) dalam urin sebagai biomarker penuaan pada pasien tuberculosis paru. Penelitian ini menggunakan pendekatan case control yakni penderita TB paru sebagai kelompok kasus dan kelompok orang sehat sebagai control dengan jumlah sampel sebanyak 50 orang ( 25 orang kasus dan 25 orang kontrol). Data dianalisis dengan menggunakan SPSS 21.0 (SPSS, Inc. Chicago, IL) dengan tingkat kemaknaan $\alpha=0$.05. Hasil penelitian menunjukkan bahwa Kadar 8-Hydroxy-deoxyguanosine (8OHdG) dalam urin sebagai biomarker penuaan pada kelompok kasus rata-rata 3.21 \pm 0.88 . Kadar 8Hydroxy-deoxyguanosine (8-OHdG) dalam urin sebagai biomarker penuaan pada kelompok kontrol ratarata $2.38 \pm 0.71$. Ada korelasi positif antara umur dengan kadar 8-Hydroxy-deoxyguanosine (8-OHdG) dalam urin sebagai biomarker penuaan $(\mathrm{p}<0,001)$, dimana semakin bertambah umur maka kadar 8Hydroxy-deoxyguanosine (8-OHdG) semakin tinggi. Terdapat perbedaan yang bermakna (p:0.001) secara statistik kadar 8-Hydroxy-deoxyguanosine (8-OHdG) sebagai biomarker penuaan antara kelompok kasus dengan kelompok kontrol. Kesimpulan penelitian ini adalah Tuberculosis paru mempercepat proses penuaan yang ditandai dengan peningkatan kadar 8-Hydroxy-deoxyguanosine (8-OHdG) dalam urine sebagai biomarker penuaan.
\end{abstract}

Kata Kunci : 8-OHdG, TB Paru , Penuaan, dan Kadar Urin

Published by:

Article history :

Tadulako University

Received : 17112021

Address:

Received in revised form : 25112021

Jl.Soekarno Hatta KM 9. Kota Palu, Sulawesi Tengah,

Accepted : 30122021

Indonesia.

Available online 31122021

Phone: +628114120202

Email: Preventif.fkmuntad@gmail.com 


\begin{abstract}
The aging process is a physiological process that cannot be avoided. Measurement of 8-oxo-dGsn in urine has the potential as a new way to evaluate the aging process in determining and estimating physiological age. This study aims to determine the level of 8-Hydroxy-deoxyguanosine (8-OHdG) in urine as a biomarker of aging in pulmonary tuberculosis patients. This study used a case control approach, namely pulmonary TB patients as a case group and a healthy group of people as a control with a total sample of 50 people (25 cases and 25 controls). Data were analyzed using SPSS 21.0 (SPSS, Inc. Chicago, IL) with a significance level of $=0.05$. The results showed that levels of 8 Hydroxy-deoxyguanosine $(8-\mathrm{OHdG})$ in urine as a biomarker of aging in the case group averaged $3.21 \pm 0.88$. The level of 8 -Hydroxy-deoxyguanosine $(8-O H d G)$ in urine as a biomarker of aging in the control group averaged 2.38 \pm 0.71 . There is a positive correlation between age and levels of 8 Hydroxy-deoxyguanosine $(8-O H d G)$ in urine as a biomarker of aging $(p<0.001)$, where the older the age, the higher the levels of 8-Hydroxy-deoxyguanosine (8-OHdG). There was a statistically significant difference (p:0.001) in the levels of 8-Hydroxy-deoxyguanosine (8-OHdG) as a biomarker of aging between the case group and the control group. The conclusion of this study is that pulmonary tuberculosis accelerates the aging process which is characterized by increased levels of 8-Hydroxydeoxyguanosine $(8-\mathrm{OHd})$ in urine as a biomarker of aging.
\end{abstract}

Keywords: 8-OHdG, Pulmonary TB, Aging, and Urine Levels

\title{
PENDAHULUAN
}

TB Paru adalah penyakit infeksi yang disebabkan oleh bakteri berbentuk basil dikenal dengan mycobacterium tuberculosis. Penularan penyakit ini melalui perantara ludah atau droplet penderita yang mengandung basil tuberculosis tersebut. Ada banyak tahapan yang perlu dilalui obat mulai dari pemberian, kemudian menghasilkan efek dan terakhir dikeluarkan dari dalam tubuh. Tahapan tersebut yaitu absorbsi, distribusi, metabolisme, dan eksresi. Obat yang berada di dalam tubuh akan dianggap sebagai benda asing oleh tubuh karena secara normal senyawa obat tidak terdapat di dalam tubuh (1)

Oleh karena itu, senyawa obat akan didetoksifikasi oleh tubuh sehingga obat tidak terlalu toksik /beracun bagi tubuh. Sebagian besar obat akan didetoksifikasi oleh hati oleh enzim-enzim mikrosomal hati. Hasilnya merupakan suatu senyawa yang sifat toksik/racunnya lebih rendah dibandingkan dengan senyawa sehingga tidak terlalu beracun bagi tubuh (2)

Penelitian mengenai perubahan status imun yang terjadi pada proses menua banyak dilakukan dengan membandingkan respon imun pada usia dewasa muda dengan usia lanjut. Banyak faktor yang dihubungkan dengan reaktivasi TB, seperti gangguan sistem imun (faktor host) dan paparan pada seseorang yang terinfeksi TB (faktor lingkungan) (3)

Kerusakan yang dihasilkan secara oksidatif terhadap asam nukleat dapat memainkan peran penting dalam proses patofisiologis berbagai penyakit. 8-oxo-7,8-dihydro-2'- 
deoxyguanosine (8-oxo-dGsn) dan 8-oxo-7,8-dihydroguanosine (8-oxo-Gsn) masingmasing adalah produk yang dihasilkan secara oksidatif dari DNA dan RNA (4)(5).

Adapun kadar normal 8-dGsn pada urin perempuan dan lelaki dewasa (20-70 tahun) adalah 138,1 dan 78,6 ng/mg kreatinin. Kerusakan oksidatif DNA dapat dinyatakan sebagai kerusakan terhadap basa dan ikatan fosfodiester DNA akibat ketiadaan perbaikan dari base excision repair (BER) dan enzim-enzim pengubah kerusakan basa oksidatif seperti DNA glikosilase, hidroksi metil urasilglikosilase dan 8-dGsn DNA glikosilase (6)(7).

Penelitian sebelumnya telah menyarankan bahwa jumlah 8-oxo-dGsn dan 8-oxo-Gsn dalam urin jauh lebih tinggi daripada cairan atau jaringan tubuh lainnya. Tujuan dari penelitian ini adalah untuk menyelidiki apakah kadar 8-oxo-dGsn dalam sampel urin acak konsisten dengan sampel urin dalam 24 jam pada subyek sehat dan pasien dengan penyakit penuaan pada TB paru. 8-oxo-7,8-dihydro-2'-deoxyguanosine (8-oxo-dGsn) salah satu biomarker penanda penuaan yang menjanjikan, yang diperlukan dalam kedokteran klinis. Pengukuran 8-oxo-dGsn dalam urin berpotensi sebagai cara baru untuk mengevaluasi proses penuaan dalam menentukan dan memperkirakan usia fisiologis. 8-oxo-dGsn juga merupakan biomarker berharga untuk paparan pekerjaan terhadap bahan kimia berbahaya (6)

Berdasarkan temuan beberapa peneliti yang mengkaji senyawa kimia alami pada urine untuk mengidentifikasi usia biologis manusia. Penelitian ini mengkaji kadar 8-OXO-7,8 Dihyroguanosine dalam urinesebagai biomarker penuaan dengan mengambil variable pasien TB Paru.

\section{METODE}

\section{Lokasi dan Rancangan Penelitian}

Penelitian ini menggunakan case control yaitu suatu penelitian analitik yang menyangkut bagaimana factor risiko dipelajari dengan menggunakan pendekatan retrospektif. Penelitian ini dilakukan di Poli Paru Kota Makassar. Populasi yang digunakan adalah pasien yang didiagnosa TB-paru. Sampel urin penderita TB paru 30- 50 tahun stadium III- IV yang berobat ke poli paru Makassar sebanyak 25orang. Dan Sampel urin kontrol, yaitu wanita dan pria yang berusia antara 30-50 tahun, sehat, dengan jumlah masingmasing 25 orang.

Sesuai dengan alur penelitian diatas, penelitian ini dimulai dengan tahap persiapan data. Sebelum memulai penelitian, peneliti mempersiapkan persuratan, perizinan, dan melakukan observasi sebelum dimulainya penelitian. Kemudian menentukan pertanyan-pertanyan terkait 

penelitian yang dituangkan ke dalam rumusan masalah. Setelah itu, menentukan populasi dan sampel penelitian sebelum masuk ke tahap pelaksanaan penelitian.

Analisis data dilakukan sesuai dengan tujuan dan skala ukur variable data yang diperoleh kemudian dianalisis melalui computer dengan menggunakan Statistical Product and Service Solution (SPSS). Hasil kemudian ditampilkan dalam bentuk narasi dilengkapi dengan tabel atau grafik variable-variabel yang diperiksa, yang akan dianalisis secara univariat untuk melihat hasil secara deskriptif. Data akan dianalisa secara bivariat menggunakan metode Chi-square dan analisis multivariat menggunakan uji T-Test.

\section{HASIL}

\section{Tabel 1}

Hubungan karakteristik dengan kadar 8-Hydroxy-deoxyguanosine (8-OHdG)

\begin{tabular}{ccccccccc}
\hline & \multicolumn{9}{c}{ Jenis Kelamin } & p value \\
\cline { 2 - 9 } Kadar 8-OhdG $(\mathbf{n g} / \mathbf{m L})$ & \multicolumn{3}{c}{ Laki-laki } & \multicolumn{3}{c}{ Perempuan } \\
\cline { 2 - 8 } & $\mathbf{n}$ & Mean & SD & $\mathbf{n}$ & Mean & SD \\
\hline Kasus (Penderita TB) & 13 & 3.27 & 0.84 & 12 & 3.15 & 0.95 & 0.726 \\
\hline Kontrol (Non-TB) & 13 & 2.46 & 0.73 & 12 & 2.29 & 0.72 & 0,580 \\
\hline
\end{tabular}

Pada hasil analisis di tabel 1 terlihat bahwa tidak terdapat hubungan yang bermakna secara statistik antara jenis kelamin dengan kadar 8-Hydroxy-deoxyguanosine (8-OHdG) pada kelompok kasus ( $p: 0.726)$ maupun pada kelompok kontrol ( $p: 0.580)$.

Tabel 2

Korelasi umur dengan kadar 8-Hydroxy-deoxyguanosine (8-OHdG)

\begin{tabular}{ccc}
\hline Kelompok & \multicolumn{2}{c}{ Umur vs Kadar 80hdG } \\
\cline { 2 - 3 } & $\mathbf{r}$ & p Value \\
\hline Kasus (Penderita TB) & 0.647 & $<0,001$ \\
\hline Kontrol (Non-TB) & 0.729 & $<0,001$ \\
\hline
\end{tabular}

Pada hasil analisis di tabel 2 terlihat bahwa terdapat korelasi positif antara umur dengan kadar 8-Hydroxy-deoxyguanosine (8-OHdG) pada kelompok kasus (r:0.647) dan bermakna secara statistik $(p<0,001)$. Demikian pula ditemukan korelasi positif antara umur dengan kadar 8-Hydroxy-deoxyguanosine (8-OHdG) pada kelompok kontrol (r: 0.729) dan bermakna secara statistik $(p<0,001)$. 

Perbedaan kadar 8-Hydroxy-deoxyguanosine (8-OHdG) antara kasus dengan kelompok kontrol

Tabel 3

Perbedaan kadar 8-Hydroxy-deoxyguanosine (8-OHdG) sebagai biomarker penuaan antara kasus dengan kelompok kontrol

\begin{tabular}{|c|c|c|c|c|c|c|c|}
\hline \multirow{3}{*}{ Variabel } & \multicolumn{6}{|c|}{ Kelompok } & \multirow{3}{*}{ p value } \\
\hline & \multicolumn{3}{|c|}{ Kasus (Penderita TB) } & \multicolumn{3}{|c|}{ Kontrol (Non-TB) } & \\
\hline & $\mathbf{n}$ & Mean & SD & $\mathbf{n}$ & Mean & SD & \\
\hline Kadar 8-OhdG & 25 & 3.21 & 0.88 & 25 & 2.38 & 0.71 & 0.001 \\
\hline
\end{tabular}

Pada Tabel 3 menunjukkan bahwa rata-rata kadar 8-Hydroxy-deoxyguanosine (8OHdG) pada kelompok kasus yaitu 3.21 $\pm 0.88 \mathrm{ng} / \mathrm{mL}$ dan rata-rata kadar 8-Hydroxydeoxyguanosine (8-OHDG) pada kelompok kontrol yaitu 2.38 $\pm 0.71 \mathrm{ng} / \mathrm{mL}$. Terdapat perbedaan yang bermakna ( $p: 0.001)$ secara statistik kadar 8-Hydroxy-deoxyguanosine (8OHdG) antara kelompok kasus dengan kelompok kontrol.

\section{PEMBAHASAN}

Hubungan Umur dengan kadar 8-Hydroxy-deoxyguanosine (8-OHdG) dalam urine sebagai biomarker penuaan

Hasil dari penelitian ini didapatkan bahwa umur berkorelasi secara positif dengan kadar 8-Hydroxy-deoxyguanosine (8-OHdG) baik pada kelompok pada kelompok kasus (r:0.647; $p$ $<0,001$ ) maupun pada kelompok kontrol (r: 0.729; $p<0,001)$ di mana semakin bertambah umur maka kadar 8-Hydroxy-deoxyguanosine (8-OHdG) semakin tinggi. Hasil penelitian ini sejalan dengan penelitian sebelumnya yang dilakukan oleh Nie et all, (2013) yang menemukan bahwa peningkatan terkait usia dalam jumlah 8-oxo-dGsn dan 8-oxo-Gsn terbukti ketika sampel urin dari tikus pada berbagai tahap pertumbuhan dianalisis.

Hasil penelitian ini juga sejalan dengan penelitian sebelumnya yang dilakukan oleh Wei Gan et all (2018) yang melakukan analisis korelasi Pearson untuk menyelidiki hubungan antara kandungan guanosin teroksidasi dan usia, dimana ditetapkan analisis korelasi dimulai pada usia 21 tahun dan berakhir pada usia 90 tahun. Hasil dari semua 1.126 sampel menunjukkan bahwa kandungan 8-oxodGsn dan 8-oxoGsn berkorelasi positif dengan umur (8-oxodGsn, $\mathrm{r}=0.337, \mathrm{p}<0.001 ; 8$-oxoGsn, $\mathrm{r}=0.580, \mathrm{p}<0.001)$. Peneliti lain yang sebelumnya juga telah melaporkan peningkatan kadar 8-oksigen urin dengan usia (8). Studi 

sebelumnya menunjukkan peningkatan tergantung usia pada dua biomarker pada tikus dan monyet (9).

Dalam penelitian ini, tren yang sama juga terjadi pada manusia. Seiring dengan bertambahnya usia, sistem anti oksidasi berkembang dengan cepat dan matang. Tingkat 8oxodGsn dan 8-oxoGsn terendah muncul pada dewasa muda (usia 11-30 tahun).

Seiring bertambahnya usia, sistem pertahanan antioksidan merosot, dan tingkat 8oksodGsn dan 8-oksoGsn meningkat secara bertahap sampai akhir hayat. Namun, perlu diperhatikan: meskipun ekskresi kreatinin banyak digunakan sebagai metode untuk menormalkan ekskresi analit melalui urin, jumlah kreatinin yang diproduksi setiap hari berkaitan dengan massa otot (10)

Hasil penelitian ini juga sejalan dengan teri proses penuaan sebelumnya bahwa penanda penuaan yang baik harus didasarkan pada mekanisme yang dijelaskan oleh teori utama penuaan, yang terutama mencakup stres oksidatif, glikasi protein, metilasi DNA, peradangan, penuaan sel, dan deregulasi hormonal (11). Harman pertama kali mengajukan teori penuaan radikal bebas pada tahun 1956, dan sejak itu, terdapat penelitian ekstensif terkait penuaan terkait ROS (12).

Reactive oxygen species (ROS) sebagai radikal bebas dan stress oksidatif terus menerus dihasilkan dalam sel hidup, menyebabkan kerusakan oksidatif pada makromolekul seluler, termasuk protein, lipid, dan asam nukleat (13).

\section{Hubungan Tuberkulosis paru dengan kadar 8-Hydroxy-deoxyguanosine (8-OHdG) dalam urine sebagai biomarker penuaan}

Hasil dari penelitian ini didapatkan bahwa terdapat perbedaan yang bermakna ( $p: 0.001)$ secara statistik kadar 8-Hydroxy-deoxyguanosine $(8-\mathrm{OHdG})$ antara kelompok kasus dengan kelompok kontrol dimana rata-rata kadar 8-Hydroxy-deoxyguanosine (8-OHdG) sebagai biomarker penuaan pada kelompok kasus yaitu $3.21 \pm 0.88 \mathrm{ng} / \mathrm{mL}$ dan rata-rata kadar 8Hydroxy-deoxyguanosine $(8-\mathrm{OHdG})$ pada kelompok kontrol yaitu $2.38 \pm 0.71 \mathrm{ng} / \mathrm{mL}$.

Radikal bebas dinyatakan sebagai molekul atau spesies yang memiliki elektron tidak berpasangan pada orbital terluarnya, bersifat tidak stabil, sangat reaktif serta berimplikasi terhadap signal transduksi dan ekspresi genetik (14).

Sebagai pengoksidan dan inhibitor terhadap enzim yang mengandung ion Fe-Sulfur, radikal bebas dapat dihasilkan secara endogen maupun eksogen baik dalam keadaan normal maupun patofisiologis. Radikal bebas dapat mengoksidasi biomolekul seperti protein, lipid, 

DNA dan juga mengakibatkan kecederaan maupun kematian sel. Oleh karena itu, efek sitotoksik radikal bebas ini akan sangat berpengaruh terhadap keadaan patogenesis (13). Salah satu indikator kerusakan DNA akibat ionisasi radiasi, mutagen atau karsinogen adalah pembentukan senyawa 8-hidroksi deoksiguanosin (8-OHdG) sebagai hasil oksidasi terhadap nukleosida DNA. Hinrichsen melaporkan bahwa tikus yang diberi pakan kekurangan kolin dapat meningkatkan kadar $8-\mathrm{OHdG}$ hati dan menginduksi pembentukan hepatoselular karsinoma pada tikus tersebut (13).

Peningkatan kadar 8-OHdG pada urin pasien tidak hanya menjadi biomarker terhadap tekanan oksidatif selular melainkan juga sebagai faktor resiko terhadap kanker, aterosklerosis dan diabetes. Adapun kadar normal 8-OHdG pada urin perempuan dan lelaki dewasa (20-70 tahun) adalah 138,1 dan 78,6 ng/mg kreatinin. Kerusakan oksidatif DNA dapat dinyatakan sebagai kerusakan terhadap basa dan ikatan fosfodiester DNA akibat ketiadaan perbaikan dari base excision repair (BER) dan enzim-enzim pengubah kerusakan basa oksidatif seperti DNA glikosilase, hidroksi metil urasilglikosilase dan 8- oksoG DNA glikosilase (13).

Bakteri tuberkulosis dapat berkontribusi terhadap pembentukan ROS di dalam tubuh.Spesies oksigen reaktif ini dapat berinteraksi dengan biomolekul seperti DNA yang menyebabkan terjadinya kerusakan DNA jika tidak diperbaiki.Mekanisme perbaikan DNA yang rusak melalui mekanisme Base Excision Repair (BER) dapat mengekskresikan DNA rusak yang terpotong.DNA yang rusak dan terpotong melalui BER ini dapat ditemukan dalam bentuk 8-hidroksi-2'-deoksiguanosin (8-OHdG). Oleh sebab itu 8-OHdG dapat digunakan sebagai biomarker risiko TB terkait paparan udara masuk ke paru (15).

Berdasarkan hasil penelitian ini dan hasil penelitian sebelumnya serta telaah terhadap teori, dapat disimpulkan bahwa tuberculosis mempercepat proses penuaan yang ditandai dengan peningkatan kadar 8-Hydroxy-deoxyguanosine $(8-\mathrm{OHdG})$ dalam urine sebagai biomarker penuaan.

\section{KESIMPULAN DAN SARAN}

Ada korelasi positif antara umur dengan kadar 8-Hydroxy-deoxyguanosine (8-OHdG) dalam urin sebagai biomarker penuaan $(p<0,001)$, dimana semakin bertambah umur maka kadar 8-Hydroxy-deoxyguanosine $(8-\mathrm{OHdG})$ semakin tinggi. Dan terdapat perbedaan yang bermakna ( $p: 0.001)$ secara statistik kadar 8-Hydroxy-deoxyguanosine (8-OHdG) antara kelompok kasus dengan kelompok kontrol. 

Perlu dilakukan penelitian dengan jumlah sampel yang lebih besar agar dapat lebih melihat peran 8-Hydroxy-deoxyguanosine $(8-\mathrm{OHdG})$ dalam menentukan umur patologis pada pasien tuberkulosis paru dan perlu dilakukan penelitian lebih lanjut terhadap kadar 8-Hydroxydeoxyguanosine $(8-\mathrm{OHdG})$ sebagai indikator proses penuaan patologis.

\section{DAFTAR PUSTAKA}

1. Tabrani R. Ilmu Penyakit Paru. Jakarta: Trans Info Media; 2010.

2. Baradero M. Klien Gangguan Ginjal. Jakarta: ECG; 2008.

3. Rilangi AR. Pulmonary Tuberculosis Risk Factors in Elderly Patienets at I Lagaligo Hospital, East Luwu Regency 2020. Angewandte Chemie International Edition, 6(11), 951-952. 2021.

4. Gan W, Nie B, Shi F, Xu XM, Qian JC, Takagi Y, et al. Age-dependent increases in the oxidative damage of DNA, RNA, and their metabolites in normal and senescenceaccelerated mice analyzed by LC-MS/MS: Urinary 8-oxoguanosine as a novel biomarker of aging. Free Radic Biol Med [Internet]. 2012;52(9):1700-7. Available from: http://dx.doi.org/10.1016/j.freeradbiomed.2012.02.016

5. Marianta D, Chahaya I, Marsaulina I. the Relation Between Physical Quality Houses With Ari. 2015;

6. Mao YH, Weng QH, Xu LN, Li XY, Zhao B, Sun Y, et al. Levels of 8-oxo-dGsn and 8oxo-Gsn in random urine are consistent with $24 \mathrm{~h}$ urine in healthy subjects and patients with renal disease. Free Radic Res [Internet]. 2017;51(6):616-21. Available from: http://dx.doi.org/10.1080/10715762.2017.1346249

7. Henriksen T, Hillestrøm PR, Poulsen HE, Weimann A. Automated method for the direct analysis of 8-oxo-guanosine and 8-oxo-2'-deoxyguanosine in human urine using ultraperformance liquid chromatography and tandem mass spectrometry. Free Radic Biol Med [Internet]. 2009;47(5):629-35. Available from: http://dx.doi.org/10.1016/j.freeradbiomed.2009.06.002

8. Nie B, Gan W, Shi F, Hu GX, Chen LG, Hayakawa H, et al. Age-dependent accumulation of 8-oxoguanine in the DNA and RNA in various rat tissues. Oxid Med Cell Longev. 2013;2013.

9. Shi F, Nie B, Gan W, Zhou XY, Takagi Y, Hayakawa H, et al. Oxidative damage of DNA, RNA and their metabolites in leukocytes, plasma and urine of Macaca mulatta: 8oxoguanosine in urine is a useful marker for aging. Free Radic Res. 2012;46(9):1093-8.

10. Marie-Desvergne C, Maître A, Bouchard M, Ravanat JL, Viau C. Evaluation of DNA

11. adducts, DNA and RNA oxidative lesions, and 3-hydroxybenzo(a)pyrene as biomarkers of DNA damage in lung following intravenous injection of the parent compound in rats. Chem Res Toxicol. 2010;23(7):1207-14.

12. Banerjee C, Ulloor J, Dillon EL, Dahodwala Q, Franklin B, Storer T, et al. Identification of serum biomarkers for aging and anabolic response. Immun Ageing. 2011;8:11-5.

13. Sakano N, Wang DH, Takahashi N, Wang B, Sauriasari R, Kanbara S, et al. Oxidative stress biomarkers and lifestyles in Japanese healthy people. J Clin Biochem Nutr. 2009;44(2):185-95. 
14. Weimann A, Belling D, Poulsen HE. Quantification of 8-oxo-guanine and guanine as the nucleobase, nucleoside and deoxynucleoside forms in human urine by high-performance liquid chromatography-electrospray tandem mass spectrometry. Nucleic Acids Res. 2002;30(2).

15. Singh R, McEwan M, Lamb JH, Santella RM, Farmer PB. An improved liquid chromatography/tandem mass spectrometry method for the determination of 8-oxo-7, 8dihydro-2'-deoxyguanosine in DNA samples using immunoaffinity column purification. Rapid Commun Mass Spectrom. 2003;17(2):126-34.

16. Gan W, Liu X Le, Yu T, Zou YG, Li TT, Wang S, et al. Urinary 8-oxo-7,8dihydroguanosine as a potential biomarker of aging. Front Aging Neurosci. 2018;10(FEB):1-8. 